\title{
PENINGKATAN PRESTASI BELAJARMATEMATIKA SISWA MELALUI PEMBELAJARAN ARIAS BERBANTUAN GEOGEBRA
}

\author{
I.K.M.A.Indrawan ${ }^{1}$, N.N.Parwati ${ }^{2}$, I.P.P.Suryawan ${ }^{3}$ \\ Jurusan Pendidikan Matematika \\ Universitas Pendidikan Ganesha, Singaraja, Indonesia \\ e-mail: botax4389@gmail.com, nyoman.parwati@undiksha.ac.id, putu.pasek@undiksha.ac.id
}

\begin{abstract}
Abstrak
Penelitian ini bertujuan untuk mendeskripsikan peningkatan prestasi belajar matematika siswa melalui penerapan ModelARIAS berbantuan geogebra dan mengetahui tanggapan siswa tentang model pembelajaran tersebut. Penelitian tindakan kelas ini terdiri dari tiga siklus, masing-masing siklus terdiri dari perencanaan, pelaksanaan, obervasi dan evaluasi dan refleksi. Subjek penelitian adalah siswa SMA kelas X BABUD semester genap tahun ajaran 2017/2018, sebanyak 35 orang. Data penelitian ini adalah data prestasi belajar dan tanggapan siswa. Data prestasi belajar matematika siswa diukur menggunakan tes prestasi belajar tipe uraian. Data tanggapan siswa diukur menggunakan angket. Data yang diperoleh dianalisis secara deskriptif. Hasil penelitian menunjukkan rata-rata tanggapan siswa terhadap model pembelajaran ARIAS berbantuan geogebra dalam kategori positif. Rata-rata nilai tes prestasi belajar matematika pada siklus I sebesar 54,28 dengan persentase siswa di atas KKM sebesar 22,85\%, kemudian pada siklus II terjadi peningkatan rata-rata nilai tes prestasi belajar matematika menjadi 64,28, dengan persentase siswa di atas KKM sebesar $62,85 \%$. Pada siklus III terjadi peningkatan rata-rata nilai tes prestasi belajar matematika menjadi 75,71 dengan persentase siswa di atas KKM sebesar $82,85 \%$. Hal tersebut terjadi karena langkah-langkah pada model ARIAS yakni yakni (1) Assurance, membangkitkan rasa percaya diri dan memotivasi siswa. (2) Relevance,menyampaikan tujuan pembelajaran dan manfaat materi yang dipelajari dalam kehidupan sehari-hari. (3) Interest, dalam tahap ini siswa diajak memelihara ketertarikan siswa terhadap pembelajaran dan melakukan eksplorasi konsep yang mereka pelajari dengan bantuan media geogebra. (4) Assessment, menguji sejauh mana siswa memahami konsep yang telah dipelajari. (5) Satisfaction,memberikan penguatan dan penghargaan bagi siswa.
\end{abstract}

Kata kunci:ARIAS, prestasi belajar, software geogebra,tanggapan siswa,.

\begin{abstract}
This study aims to describe the improvement of students' mathematics learning achievement and student responses through the application of the ARIAS Model assisted by Geogebra App. This classroom action research consists of three cycles, each cycle consist of planning, implementation, observation and reflection. The subjects were 35 high school students of class X BABUD in even semester school year 2017/2018. The data of this study were data on student achievement and student responses. The data of students' mathematics learning achievement was measured using a description type learning achievement test. Student response data was measured using a questionnaire. The data obtained were analyzed descriptively. The results showed an average student response of 53.28 in the positive category. The average score of the mathematics learning achievement test in the first cycle was 54.28 with the percentage of students above the minimum criteria of mastery of $22.85 \%$, and then in the second cycle there was an increase in the average score of mathematics learning achievement test to 64.28 , with the percentage of students in the minimum criteria of mastery was $62.85 \%$. In the third cycle there was an increase in the average value of the mathematics learning achievement test to 75.71 with the percentage of students above the minimum criteria of mastery of $82.85 \%$. This happens because of the steps in the ARIAS model which called (1) Assurance, (2) Relevance, (3) Interest, (4) Assessment, (5) Satisfaction are able to improve the two factors that influence students' mathematics learning process, the internal factors and the external factors. By improving the confidence and interest of the students which called the internal factors and improve the atmosphere of the classroom which called the external factor of the students.
\end{abstract}

Keywords: ARIAS, Geogebra software, learning achievement, students' response 
Jurnal Pendidikan dan Pembelajaran Matematika Indonesia

Vol. 7 No. 1, Tahun 2018

e-ISSN : 2615-7454

\section{Pendahuluan}

Matematika merupakan dasar perhitungan dan penalaran yang diperlukan dalam kehidupan sehari-hari. Hakikatnya, matematika merupakan ilmu terstruktur di mana konsepkonsep tersusun sistematis dan logis mulai dari konsep paling sederhana sampai pada konsep paling kompleks. Oleh karena itu, belajar matematika diartikan sebagai belajar tentang konsep-konsep dan struktur-struktur yang terdapat dalam bahasan yang dipelajari serta mencari hubungan-hubungan antara konsep-konsep dan struktur tersebut. Dalam matematika terdapat topik yang memiliki konsep sebagai prasyarat atau dasar untuk memahami konsep selanjutnya. Berdasarkan hal tersebut, matematika diprogramkan sebagai salah satu mata pelajaran wajib di setiap jenjang pendidikan, dengan harapan setiap individu dapat meningkatkan kemampuan matematikanya. Salah satu tolak ukur untuk mengetahui kemampuan matematika seseorang adalah prestasi belajar.

Prestasi Belajar adalah nilai sebagai rumusan yang diberikan guru bidang studi mengenai kemajuan atau prestasi belajar selama masa tertentu. (Sumadi Suryabrata, 1998). Oleh karena itu sangat penting bagi guru untuk membatu siswa meningkatkan prestasi belajar mereka untuk mengetahui apakah tujuan dari pembelajaran sudah tercapai atau belum dan untuk di jadikan reverensi untuk memperbaiki proses pembelajaran.

Berdasarkan data-data seperti tugas dan ulangan harian terlihat prestasi belajar siswa yang merupakan tolak ukur berhasilnya proses pembelajaran di kelas masih tergolong rendah khususnya siswa di kelas X BABUD.Prestasi belajar siswa sebagian besar masih di bawah Kriteria Ketuntasan Minimal (KKM) dengan nilai rata - rata ulangan harian siswa sebesar 58.64 sedangkan KKM yang di tentukan adalah 65.

Adapun penyebab permasalahan dalam pembelajaran matematika di kelas tersebut, diantaranya rendahnya antusias siswa untuk mengikuti pembelajaran yang dapat dilihat dari pembelajaran terlalu berpusat pada guru dan siswa terlihat pasif dalam mengikuti pembelajaran. Siswa juga terlihat kurang percaya diri untuk menjawab pertanyaan yang diberikan oleh guru, bahkan pada saat ditunjuk perseorangan siswa terlihat takut dan ragu untuk menjawab pertaanyaan dari guru. Siswa seperti merasa materi yang dipelajarinya tidaklah berguna bagi kehidupannya. Contoh yang diberikan oleh guru jarang dikaitkan dengan kehidupan sehari-hari dan media yang digunakan dalam pembelajaran masih sangat minim.

Salah satu solusi yang dapat digunakan untuk mengatasi permasalahan di kelas $X$ BABUD adalah mengganti model pembelajaran konvensional menjadi model pembelajaran yang lebih menarik dan inovatif, yaitu dengan menerapkan model pembelajaran ARIAS. Model pembelajaran merupakan suatu kerangka atau rancangan yang menggambarkanproses pembelajaran yang terjadi di dalam suatu kelas, untuk mencapai tujuan pembelajaran tertentu yang memiliki fungsi sebagai pedoman bagi pendidik dalam menjalankan proses belajar mengajar. (Parwati, Pasek dan Ratih, 2018) Model pembelajaran $A R I A S$ dipilih karena memiliki sintak yang berfokus pada peningkatan minat dan rasa percaya diri siswa yang terlihat dari 3 bagian inti dalam model pembelajaran ini yaitu bagian Assurance, Relevance dan Interest. Pada bagian Assurance siswa diberi motivasi untuk menumbuhkan rasa percaya dirinya, dibagian Relevance siswa diajak mengetahui manfaat dari materi yang mereka pelajari untuk memotivasi siswa bahwa materi yang mereka pelajari tidaklah percuma dan dibagian Interest guru menjelaskan materi sambil menumbuhkan dan menjaga ketertarikan siswa terhadap pembelajaran dengan metode-metode yang beragam. Melalui tiga bagian inti yang terdapat dalam model pembelajaran ARIAS inilah, kelemahan pembelajaran yang terdahulu dapat diatasi.

Demi mendapat hasil yang lebih maksimal digunakan software geogebra sebagai software pembantu implementasi model pembelajaran ARIAS. Dipilinnya software geogebra sebagai pembantu implementasi model pembelajaran ARIAS mengingat minimnya dan kurang menariknya media pembelajaran matematika yang selama ini digunakan di kelas $X$ BABUD. Dengan menggunakan software geogebra dapat dihasilkan berbagai media pembelajaran yang menarik dengan fitur efek yang cukup realistis. Efek yang realistik dapat 
menarik minat siswa dalam belajar matematika sehingga dapat meningkatkan kualitas proses pembelajaran yang terjadi

Beberapa penelitian menunjukkan model pembelajaranARIAS memberikan pengaruh yang baik terhadap berbagai kegiatan pembelajaran. Beberapa kajian yang mendukung penerapan model ini adalah Virginayoga (2013) menunjukkan bahwa model pembelajaran ARIAS dapat meningkatkan keaktifan siswa di kelas. Dalam penelitian Tri Puspayanti (2016) terungkap bahwa model pembelajaran ARIAS berpengaruh positif terhaap motivasi dan prestasi belajar matematika siswa. Penelitian Sinta Suryanti (2017) menunjukkan bahwa model pembelajaran $A R I A S$ dapat meningkatkan kemampuan dan aktivitas pemecahan masalah siswa. Implementasi model pembelajaran ARIAS yang dilakukan oleh Hertina (2017) juga menunjukkan bahwa model ini dapat meningkatkan aktivitas belajar siswa dan pemahaman konsep matematika siswa. Hasil-hasil penelitian tersebut semakin memperkuat indikasi bahwa implementasi model pembelajaran ARIAS dalam pembelajaran matematika dapat meningkatkan minat dan rasa percaya diri siswa yang pada akhirnya dapat meningkatkan prestasi belajar matematika siswa.

Berdasarkan hasil observasi dan wawancara dengan guru matematika, disepakati bahwa solusi yang tepat adalah dengan menerapkan Model PembelajaranARIAS berbantuan geogebra. Dengan menerapkan model tersebut diyakini dapat meningkatkan pemahaman konsep matematika serta memperkuat pengetahuan yang sudah dimiliki siswa.

\section{Metode Penelitian}

Penelitian ini termasuk dalam jenis penelitian tindakan Kelas (classroom action research) yang dibagi menjadi dua tahapan kegiatan yaitu refleksi awal dan pelaksanaan penelitian dalam tiga siklus yang setiap siklusnya terdiri atas empat tahapan, yaitu perencanaan tindakan, pelaksanaan tindakan, observasi, serta refleksi. Penelitian ini ditujukan untuk meningkatkan prestasi belajar matematika siswa dan mengetahui tanggapan siswa terhadap model pembelajaran yang diterapkan.

Subjek penelitian ini adalah siswa kelas menengah semester genap tahun ajaran 2017/2018 sebanyak 35 siswa. Alasan dilakukan pada siswa kelas menengah, karena di kelas tersebut prestasi belajar matematika siswa masih kurang. Objek dalam penelitian tindakan kelas ini adalah peningkatanprestasi belajar yang dapat dicapai melalui implementasi Model PembelajaranARIAS berbantuan geogebra.

Instrumen yang digunakan dalam penelitian ini adalah berupa tes, angket tanggapan siswa dan jurnal harian. Tes yang digunakan untuk mengumpulkan data terkait prestasi belajar matematika siswa adalah tes prestasi belajar berbentuk uraian. Data prestasi belajar matematika siswa dikumpulkan pada tahap evaluasi siklus. Sedangkan angket digunakan untuk mengumpulkan data mengenai tanggapan siswa terhadap model pembelajaran yang diterapkan dan jurnal harian digunakan untuk mencatat temuan-temuan yang didapat disetiap pertemuan. Data tanggapan siswa dikumpulkan dengan menggunakan angket tanggapan yang terdiri dari 15 item pernyataan yang diberikan pada akhir siklus III. Kriteria penskoran tanggapan siswa menggunakan skala Lickert dengan pilihan yaitu Sangat Setuju (SS), Sejutu (S), Tidak Setuju (TS), dan Sangat Tidak Setuju (STS). Sebelum digunakan, tes uraian dan angket diuji validitas oleh dua orang dosen Jurusan Pendidikan Matematika Undiksha.

Setelah data prestasi belajar matematika siswa dan data tanggapan siswa terhadap penerapan Model PembelajaranARIAS berbantuan geogebraterkumpul, selanjutnya data tersebut dianalisis secara deskriptif, yaitu dengan menghitung rata-rata skor prestasi belajar matematika siswa untuk data prestasi belajar matematika dan rata-rata skor tanggapan siswa untuk data tanggapan siswa. Kriteria yang digunakan dalam ketuntasan prestasi belajar matematika siswa dan penggolongan kriteria untuk tanggapan siswa terhadap Model Pembelajaran ARIAS berbantuan geogebradapat dinyatakan dalamTabel 1 dan Tabel 2. 
Tabel 1. Kriteria Ketuntasan Prestasi Belajar Matematika Siswa

\begin{tabular}{lll}
\hline No & Skor & Kualifikasi \\
\hline 1 & $65 \leq \bar{X} \leq 100$ & Tuntas \\
\hline 2 & $\bar{X}<65$ & Belum Tuntas \\
\hline
\end{tabular}

Tabel 2. Kriteria Penggolongan Tanggapan Siswa yang Telah Dimodifikasi dengan Skor Kuisioner Tanggapan Siswa

\begin{tabular}{cll} 
No & Rentangan Skor & \multicolumn{1}{c}{ Kategori } \\
\hline 1 & $60 \leq \bar{T}<75$ & Sangat positif \\
\hline 2 & $50 \leq \bar{T}<60$ & Positif \\
\hline 3 & $40 \leq \bar{T}<50$ & Cukup positif \\
\hline 4 & $30 \leq \bar{T}<40$ & Kurang positif \\
\hline 5 & $15 \leq \bar{T}<30$ & Sangat kurang positif \\
\hline
\end{tabular}

\section{Hasil Penelitian}

Penelitian ini telah dilaksanakan dalam tiga siklus. Setiap siklus terdiri dari empat tahapan yaitu perencanaan tindakan, pelaksanaan tindakan, observasi, serta refleksi. Data yang dikumpulkan dalam penelitian ini terkait data prestasi belajar matematika siswa dan data mengenai tanggapan siswa terhadap Model PembelajaranARIAS berbantuan geogebra. Data yang telah dikumpulkan dianalisis sesuai dengan teknik analisis data yang telah ditetapkan sebelumnya. Hasil analisis data prestasi belajar matematika siswa, serta analisis tanggapan siswa terhadap Model PembelajaranARIAS berbantuan geogebradipaparkan sebagai berikut.

A. Prestasi Belajar Matematika

Berdasarkan hasil penelitian yang sudah dilaksanakan, prestasi belajar matematika siswa kelas menengah dari siklus I sampai siklus III dapat dinyatakan dalam tabel 3.

Tabel 3. Ringkasan Hasil Prestasi Belajar Matematika Siswa

\begin{tabular}{cccc}
\hline Siklus & $\begin{array}{c}\text { Jumlah } \\
\text { Nilai }\end{array}$ & $\begin{array}{c}\text { Rata- } \\
\text { rata }\end{array}$ & $\begin{array}{c}\text { Ketuntasan } \\
\text { Belajar Siswa }\end{array}$ \\
\hline I & 1900,00 & 54.28 & $22.85 \%$ \\
\hline II & 2300,00 & 64.28 & $62.85 \%$ \\
\hline III & 2650,00 & 75.71 & $82.85 \%$ \\
\hline
\end{tabular}

Dari Tabel3 dapat dilihat bahwa adanya peningkatan rata-rata nilai prestasi belajar matematika siswa dari siklus I sampai siklus III. Pada siklus I, nilai rata-rata prestasi belajar matematika siswa 54,28 dan mengalami peningkatan pada siklus II yakni menjadi 64,28. Pada siklus III, rata-rata nilai pretasi belajar matematika siswa meningkat menjadi 75,71 . Berdasarkan data tersebut terlihat model pembelajaran ARIAS berbantuan geogebra dapat meningkatkan prestasi belajar matematika siswa. 
Jurnal Pendidikan dan Pembelajaran Matematika Indonesia

Vol. 7 No. 1, Tahun 2018

e-ISSN : 2615-7454

B. Tanggapan Siswa

Diagram tanggapan siswa dapat dilihat pada Gambar 1.

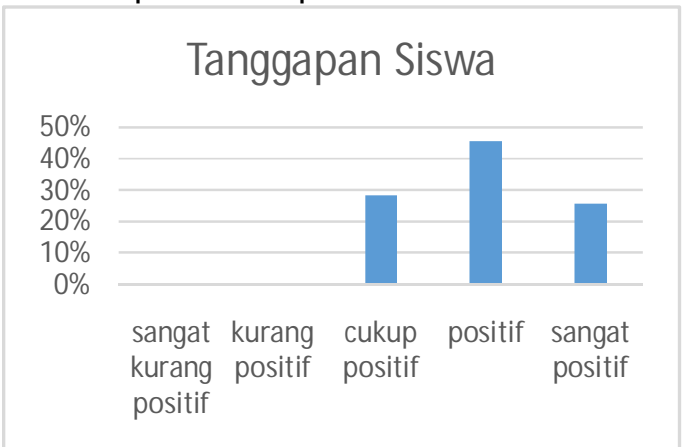

Gambar 1. Diagram tanggapan siswa terhadap model pembelajaran ARIAS berbantuan geogebra

Dari Gambar 1 terlihat bahwa tanggapan siswa terhadap pembelajaran matematika yang diterapkanberada pada kategori positif dengan data sebagai berikut. 10 siswa memberi tanggapan cukup positif, 16 siswa memberi tanggapan positif, dan 9 siswa memberi tanggapan sangat positif. Berdasarkan hasil tersebut model pembelajaran ARIAS berbantuan geogebra memperoleh tanggapan yang positif dan dapat diterapkan di kelas untuk meningkatkan prestasi belajar matematika siswa.

\section{Pembahasan}

Berdasarkan hasil penelitian yang telah dilaksanakan dalam tiga siklus terlihat bahwa prestasi belajar matematika siswamengalami peningkatan dari refleksi awal sampai siklus III. Hal ini ditinjau dari rata-rata skor prestasi belajar matematika siswa dan ketuntasan belajar yang telah memenuhi indikator keberhasilan.

Secara umum tercapainya tujuan penelitian ini tidak lepas dari implementasi dari model pembelajaran ARIAS berbantuan geogebra, yang membantu siswa menjadi lebih percaya diri dan memberikan kesempatan siswa untuk lebih aktif dalam menyelesaikan permasalahan yang diberikan. Adapun hal-hal yang menyebabkan terjadinya peningkatan prestasi belajar matematika siswaadalah sebagai berikut.

Pertamamodel pembelajaran ARIAS selalu memberitaukan manfaat dan tujuan dari materi yang di pelajari oleh siswa sehingga tujuan pembelajaran menjadi jelas. Dengan jelasnya tujuan yang ingin di capai siswa menjadi lebih termotivasi untuk mengikuti pembelajaran.Hal ini sejalan dengan penelitian yang dilakukan oleh $\mathrm{Ni}$ Komang Tri Puspayanti (2016) penelitanya menyatakan bahwa model pembelajaran ARIAS berpengaruh positif terhadap motivasi siswa di kelas VII SMP Negeri 5 Melaya.

Kedua model pembelajaran ARIAS memberi banyak ruang untuk siswa untuk lebih aktif dalam menyelesaikan masalah yang telah diberikan di LKS dan mengajak siswa lebih kreatif untuk menemukan pemecahan dari permasalahan tersebut. Hal ini sejalan dengan penelitian yang dilakukan oleh Sang Ayu Made Hertina (2017) yang menunjukkan bahwa model pembelajaran ARIAS dapat meningkatkan aktivitas dan pemahaman konsep matematika siswa.

Ketiga bantuan dari software geogebra yang memberikan visualisasi yang lebih nyata sehingga memudahkan siswa memahami dan menggabarkan materi ataupun masalah yang sedang dihadapi siswa dalam pembelajaran. Hal ini sesuai dengan penelitian yang dilakukan oleh I Gusti Ayu Putu Muda Apriyanti (2016). Hasil yang ditemukan dalam penelitian Apriyanti adalah bantuan dari software geogebra berpengaruh positif terhadap prestasi belajar siswa.

Keempat bantuan dari software geogebra membantu siswa memahami konsep yang dipelajari dengan memberikan gambaran visual dari konsep tersebut. Hal ini sejalan dengan penelitin yang dilakukan oleh I Made Adi Wira Nata Putra (2016) Penelitiannya 
menghasilkan kesimpulan bahwa penerapan model pembelajaran kooperatif tipe group investigation berbantuan media pembelajaran berbasis geogebra dapat meningkatan pemahaman konsep matematika siswa kelas VIIIA SMP Negeri 1 Gianyar.

Kelima model pembelajaran ARIAS dengan bantuan geogebra yang menjaga ketertarikan siswa terhadap pembelajaran yang dipelihara dengan memberikan media pembelajaran yang menarik dan system diskusi yang diterapkan membuat siswa tidak bosan. Hal ini sejalan dengan penelitian yang dilakukan oleh I Made Budi Adnyana (2016) yang menyatakan penerapan LKS interaktif berbasis software geogebra dengan setting pembelajaran think pair share dapat meningkatkan Aktivitas belajar dan pemahaman konsep matematika siswa kelas XI MIPA 5 SMAN 4 Singaraja.

\section{Simpulan Dan Saran} berikut.

Berdasarkan hasil penelitian dan pembahasan, dapat diperoleh simpulan sebagai

1. Penerapan Model Pembelajaran ARIAS berbantuan geogebra mampu meningkatkan prestasi belajar matematika siswa kelas X BABUD SMA Negeri 1 Mendoyo secara kuantitatif. Peningkatan tersebut terjadi karena langkah-langkah pada model ARIAS yakni yakni (1) Assurance, dalam tahap ini rasa percaya diri siswa di bangkitkan dengan memberi motivasi kepada siswa dan mengingatkan siswa tentang materi prasyarat. (2) Relevance, dalam tahap ini siswa diajak menyimak tujuan pembelajaran sehingga pembelajaran menjadi terarah dan siswa juga diajak mengetahui penggunaan materi yang dipelajari dalam kehidupan sehari-hari sehingga siswa tau manfaat dari pembelajaran yang mereka lakukan. (3) Interest, dalam tahap ini meningkatkan daya tarik siswa terhadap pembelajaran dengan membuat siswa bereksplorasi dengan konsep yang mereka pelajari dengan bantuan media geogebra. (4) Assessment, dalam tahap ini diuji sudah sejauh mana siswa memahami konsep yang telah dipelajari. (5) Satisfaction, dalam tahap ini siswa diberikan penguatan dan penghargaan bagi siswa yang aktif dalam pembelajaran dengan memberikan nilai tambahan untuk siswa tersebut dan untuk siswa yang kurang juga diberikan penguatan dan motivasi agar siswa menjadi bersemangat untuk lebih aktif dalam pembelajaran berikutnya.

2. Tanggapan siswa kelas $X$ BABUD SMA Negeri 1 Mendoyo terhadap penerapan Model Pembelajaran ARIAS Berbantuan Geogebra tergolong positif yakni dengan rata-rata skor tanggapan siswa sebesar 53,28.

Berdasarkan hasil penelitian yang diperoleh, adapun saran-saran yang dapat disampaikan sebagai berikut

1. Diharapkan Model Pembelajaran ARIAS Berbantuan Geogebra dapat dijadikan salah satu alternatif dalam melaksanakan pembelajaran matemtaika, sehingga pembelajaran yang dilaksanakan lebih variatif seperti yang telah dilaksanakan sebelumnya dan dapat meningkatkan prestasi belajar matematika siswa.

2. Kepada pembaca yang berminat untuk mengadakan penelitian lebih lanjut sebagai penyempurnaan mengenai Model Pembelajaran ARIAS Berbantuan Geogebra dengan memperhatikan kendala-kendala yang peneliti alami sebagai bahan pertimbangan.

\section{Daftar Pustaka}

Apriyanti, I.G.A.P.M, Sadra, I.W, dan Djoko, W. 2016. "Pengaruh model Pembelajaran Learning Cycle 7 E Berbantuan Media Geogebra terhadap Prestasi Belajar Matematika Siswa kelas VIII SMP Negeri 3 Singaraja". Skripsi (Tidak Diterbitkan). Jurusan Pendidikan Matematika, UNDIKSHA Singaraja.

Budi, A.I.M, Suparta, I.N, dan Wisna, A.P. 2016. "Penerapan LKS Interaktif berbasis Software Geogebra dengan setting Pembelajaran Think Pair Share Untuk Meningkatkan Aktivitas Belajar dan pemahaman konsep Matematika Siswa Kelas XI MIPA 5 SMAN 4 Singaraja”. Skripsi (Tidak Diterbitkan). Jurusan Pendidikan Matematika, UNDIKSHA Singaraja.

Jurnal Pendidikan dan Pembelajaran Matematika Indonesia | 84 
Hertina, S.A.M,Parwati, N.N, Puja, A.I.P. 2017. "Peningkatan Aktivitas Belajar Siswa dan Pemahaman Konsep Matematika Siswa Kelas VII B SMP Negeri 1 Bangli Melalui Penerapan Model Pembelajaran ARIAS”. Skripsi (Tidak Diterbitkan). Jurusan Pendidikan Matematika, UNDIKSHA Singaraja.

Parwati, N.N, Mertasari, S.N.M, dan Ambarawati, I.A.D. 2015."Pengaruh Pelaksanaan Pendekatan Saintifik Berorientasi Kearifan Lokal Berbantuan Media Manipulatif Terhadap Prestasi Belajar Matematika Siswa SD di Kota Singaraja". Jurnal Pendidikan Matematika Undiksha. Vol.3, No.1, Tahun 2015.

Parwati, N.N, Pasek, S,I.P, dan Ratih, A.A. 2018. Belajar dan Pembelajaran. Depok: Rajawali Pers.

Puspayanti, T.N.K, Mertasari, S.N.M, dan Pasek, S.I.P. 2016.” Pengaruh Model Pembelajaran ARIAS (Assurance, Relevance,Interest,Asessment, and Satisfaction) Terhadap Motivasi dan Prestasi Belajar Matematika Siswa Kelas VII SMP Negeri 5 Melaya”. Skripsi (Tidak Diterbitkan). Jurusan Pendidikan Matematika, UNDIKSHA Singaraja

Risma, H.P.S, Wisna, A.P, dan Passek, S.I.P. 2016. "Pengaruh Penggunaan LKS Berbantuan Geogebra Terhadap Prestasi Belajar Siswa Kelas X SMA Laboratorium Undiksha Singaraja”. Skripsi (Tidak Diterbitkan). Jurusan Pendidikan Matematika, UNDIKSHA Singaraja

Sinta, S.N.L, Sudiarta, I.G.P, dan Ardana, I.M. 2017. "Penerapan Model Pembelajaran ARIAS Berbantuan Video Pembelajaran Untuk Meningkatkan Kemampuan dan Aktivitas Pemecahan Masalah Siswa Kelas X-1 SMA Labotarorium Undiksha Singaraja”. Jurnal Pendidikan Matematika Undiksha. Vol.8,No.2, Tahun 2017.

Sumadi, S, 1998. Psikologi Pendidikan. Jakarta: PT. Raja Grafindo Persada.

Virginayoga, H.L, Pujawan, I.G.N, dan Djoko, W. 2015.” Implementasi Model Pembelajaran ARIAS Bermuatan Masalah Realistik untuk Meningkatkan Kemampuan Koneksi Matematis dan Self Esteem Siswa Kelas X Akomodasi Perhotelan 4 SMK Negeri 2 Singaraja”. Skripsi (Tidak Diterbitkan). Jurusan Pendidikan Matematika, UNDIKSHA Singaraja.

Wira, N.P.I.M.A, Djoko, W, dan Wisna, A.P. 2016. "Penerapan Model Pembelajaran Kooperatif Tipe Group Investigation Berbantuan Media Pembelajaran Berbasis Geogebra untuk meningkatkan pemahaman konsep Matematika Siswa Kelas VIIIA SMP Negeri 1 Gianyar Semester Genap tahun Ajaran 2015/2016”. Jurnal Pendidikan Matematika Undiksha. Vol.8,No.2, Tahun 2017

Yasa, I.M.A, Sadra, I.W, dan Suweken, G. 2013."Pengaruh Pendidikan Matematika Realistik dan Gaya Kognitif Terhadap Prestasi Belajar Matematika Siswa". Jurnal Penelitian Pasca Sarjana. Vol.2, Tahun 2013 